DIW BERLIN

Discussion

Papers

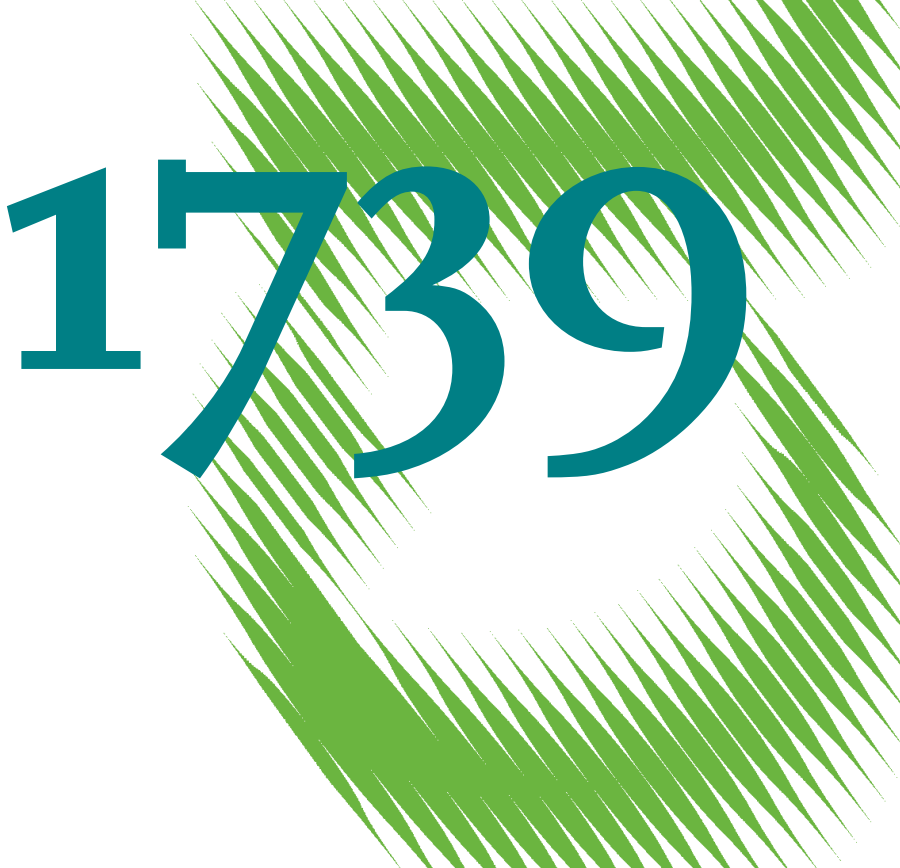

The Impact of Institutions on Bank Governance and Stability: Evidence from African Countries 
Opinions expressed in this paper are those of the author(s) and do not necessarily reflect views of the institute.

IMPRESSUM

(C) DIW Berlin, 2018

DIW Berlin

German Institute for Economic Research

Mohrenstr. 58

10117 Berlin

Tel. +49 (30) $89789-0$

Fax +49 (30) $89789-200$

http://www.diw.de

ISSN electronic edition 1619-4535

Papers can be downloaded free of charge from the DIW Berlin website:

http://www.diw.de/discussionpapers

Discussion Papers of DIW Berlin are indexed in RePEc and SSRN:

http://ideas.repec.org/s/diw/diwwpp.html

http://www.ssrn.com/link/DIW-Berlin-German-Inst-Econ-Res.html 


\title{
The Impact of Institutions on Bank Governance and Stability: Evidence from African Countries*
}

\author{
Samuel Mutarindwa ${ }^{\dagger} \quad$ Dorothea Schäfer ${ }^{\ddagger} \quad$ Andreas Stephan \\ May 2018
}

\begin{abstract}
This paper sheds new light on how African countries' legal systems and institutions influence the governance and stability of their banks. We find that institutional factors, in particular the legal family of origin, political stability, contract enforcement and strength of investor protection promote central corporate governance reforms. Using a difference-in-difference approach, we also reveal that those reforms mediate the impact of institutions on banks. If countries have a corporate governance reform in place their banks show better internal governance and higher stability.
\end{abstract}

Key Words: African banks, corporate governance, legal systems, institutions, bank stability

JEL codes: G21,G28,G30,G32,G38

${ }^{*}$ We thank seminar participants at the CeFEO seminar in January 2018 for helpful comments and suggestions on a previous version of the paper. The usual disclaimer applies

${ }^{\dagger}$ Samuel.Mutarindwa@ju.se, Jönköping International Business School

‡dschaefer@diw.de, DIW Berlin, Germany; JIBS, Sweden; and CERBE, Italy;

§andreas.stephan@ju.se, Jönköping International Business School and CESIS Stockholm 


\section{Introduction}

Banks play important roles in financial intermediation through deposit mobilization, money transfers and lending to firms and households in all economies. In developing countries, especially those of Africa, banks are by far the most important contributors to their financial system development, since alternative sources of finance such as capital markets are limited. Thus, bank governance and stability is crucial. Any form of bank failure may result in contagious effects on the entire financial system. Consequently, countries have implemented reforms and directives to make bank focus on reducing risks which could adversely affect bank stability.

Previous studies have examined country-level determinants of bank stability including regulations, bank supervision (Barth, Caprio Jr, \& Ross, 2004; Laeven \& Levine, 2009) and deposit insurance (Anginer, Demirguc-Kunt, \& Zhu, 2014; Demirgüç-Kunt \& Detragiache, 2002). These studies link bank risk-taking to differences in countries' domestic regulation and supervisory strengths. However, they focus on hard regulations specifically the Basel compliance principles (BCP). Evidence about how bank stability is affected by soft laws (codes) designed by sovereign central banks as a way of complementing hard regulations is absent in this empirical literature.

Another strand of literature that deals with banks at the of micro-level borrows from law and finance literature and links countries' legal systems, and institutions with bank stability (Essid, 2014; Fang, Hasan, \& Fang, 2014; Haselmann \& Wachtel, 2010; Houston, Lin, Lin, \& Ma, 2010). This research suggests that institutional development indicated by strengths of creditor rights, information sharing on borrowers and contract enforcement affects bank lending and risk taking. However, the focus is only on the emerging economies of Europe and Asia. Evidence about the effects of legal reforms and institutional changes on African banks is rather scarce. We address this research gap and borrow from both strands of literature to evaluate how African countries' legal systems and institutions influence governance and stability of their banks.

Although there are differences among African countries brought about by culture and history, evidence shows that in terms of financial systems, African countries have many features in common. African banks are both highly liquid and well capitalized compared to other regions of the world. Beck and Cull (2014) report that the ratio of liquid assets to short term funding is 42.9 percent in African banks but only 29.3 percent in non-African banks. However, they also reveal higher non-performing loan ratios in African banks. Similarly, Nana and Samson (2014) report that liquid reserves to total assets in African banks are between 11 and 19 percent compared to only 5 percent for OECD banks. Beck, Maimbo, Faye, and Triki (2011) show that African countries are characterized by a large informal sector. Information about individuals and firms is scarce and difficult to ob- 
tain. The near absence of credit bureaus and credit registries create severe information asymmetries between borrowers and lenders. In response, banks tend to lend little to the private sector and invest more often in safer government securities with transparent and easily accessible credit information. Such institutional differences result in higher levels of credit risks and non-performing loans. At the same time, many African countries suffer from high levels of corruption (Okike, 2007; Wanyama, Burton, \& Helliar, 2009) which may adversely affect enforcement of loan repayment.

Complementary to this research, we analyze the importance of institutional progress for improving internal corporate governance and stability of African banks. Specifically, we address the mediating role of national corporate governance reforms in transforming institutional progress into improvements at the individual bank level. Bank stability is measured using performance as well as resilience indicators (Ashraf, 2017; Klomp \& de Haan, 2015; Laeven \& Levine, 2009). We employ a difference-in-difference approach to identify this impact (Angrist \& Pischke, 2009; Fang et al., 2014). Banks from countries in which central banks published bank-specific corporate governance code are taken as the treatment group while the control group consists of banks from non-publishing countries. The sample consists of 216 banks from 44 African countries over the period 2005-2015. We use websites of countries' central banks to identify those countries that have published bank-specific corporate governance codes and those that have none in place. Institutional development indicators are taken from the World Governance indicators (Kaufmann \& Kraay, 2008) and from the World Bank doing business reports. Legal systems are measured using the classification introduced by LaPorta, de Silanes, Shleifer, and Vishny (1998).

The empirical results show that - mediated via national governance reforms - good institutions at the country level improve banks' internal governance, increase return figures and strengthen resilience. Banks operating in common-law countries with strong institutional quality are more likely to internally implement the published national corporate governance codes than their peers from countries with civil-law tradition, and those banks have also higher Z-scores. Our results are robust to using alternative indicators for stability.

Successful banks may have superior governance and lobby for a better governance system countrywide. In this case bank level governance and performance would be an important driver for the introduction of nation-wide corporate governance codes and not the other way round. We address this potential endogeneity problem in different ways. First, we use a two-equation model of bank-level outcomes and introduction of national corporate governance codes, and allow for correlation between the regression residuals of the equations. Second, we include bank fixed effects to control for omitted variables. Our 
results remain significant and robust.

Our study contributes to the literature in several ways. First, we add to the banking regulation literature and provide evidence on the channels through which the nation-wide introduction of corporate governance codes influence bank governance and stability. Our paper is closely related to Akhigbe and Martin (2008) and Akhigbe and Martin (2006). They show in cross-section analyses, the relevance of the SOX (Sarbenes-Oxley Act) governance compliance and disclosure provisions for bank risk taking in the US. Financial institutions that increased disclosures and adjusted governance as required by the SOX report were able to improve valuation and reduce risks in the long-run. We compliment this literature by adding panel-data based evidence on the question of how compliance to central banks' corporate governance recommendations affects African banks' risk taking.

Second, we complement the research examining the influence of institutional factors on bank stability (Ashraf, 2017; Cole \& Turk-Ariss, 2013; Essid, 2014; Fang et al., 2014; Haselmann \& Wachtel, 2010; Houston et al., 2010; Qian, Cao, \& Cao, 2018; Zhang, Wang, \& Qu, 2012). The studies focusing on banks from transition, emerging and European developed countries suggest that among other factors, institutional differences and legal origins lead to differences in bank stability and performance. In particular, they reveal that institutions have first-order effects on performance. We show that in African countries institutions have second-order effects. Institutions increase the likelihood that central corporate governance reforms will be implemented at the bank level and subsequently increase bank stability in these countries.

Fang et al. (2014) argue that countries' institutions amplify or impede the effects of bank reforms on bank stability. We add to this small empirical literature by focusing on bank-specific codes instead of considering generic corporate governance reforms that apply to all public companies. Those codes are published by central banks as part of the regulation and are, thus, more powerful than general governance recommendations. Finally, we provide empirical evidence on institutional determinants of bank stability in Africa which is noticeably almost missing in this strand of literature. Only Andrianova, Baltagi, Demetriades, and Fielding (2015) assess the influence of institutions on bank lending in 32 African countries. We move beyond this study by exploring both the impact of country-wide governance reforms on internal governance and on bank stability.

The remainder of this paper is organized as follows. Section 2 reviews the previous literature on international corporate governance and derives testable propositions, paying special attention to the determinants of bank level practices and the impact of interactions among country-level and bank-level corporate governance on performance and stability. Section 3 presents the methodology and data including data sources and operationalization of variables. Section 4 analyzes and discusses the results of the study. The concluding 
Section 5 highlights the study's contribution.

\section{Literature review and research hypotheses development}

\subsection{The link of corporate governance codes with bank governance and stability}

Since the 1980s and 90s most African countries have undertaken financial reforms supported by the Bank for International settlements and the IMF (Triki, Kouki, Dhaou, \& Calice, 2017) subsequent to banking crises. In addition to capital and supervisory regulations, countries have implemented specific bank corporate governance codes. These codes are published by central banks and provide recommendations on the structure, composition and functioning of boards. They aim at enhancing not only the stability of the entire financial systems but also at protecting investors from expropriations by controlling block-holders. This could be a severe threat in many developing countries where majority banks are closely held. Large (controlling) shareholders may expropriate diffuse small shareholders by investing in risky projects. Marginal shareholders have insufficient information and instruments to monitor both bank managers and inside shareholders. Corporate governance codes could improve the small stakeholders position by empowering boards to closely monitor the activities of both groups. Efficient boards can be expected to have a better chance to prevent excessive risk taking.

Empirical studies examining the influence of corporate governance provisions on risktaking of banks usually focus on other regions and neglect African countries. Akhigbe and Martin (2006) and Akhigbe and Martin (2008) assess the relevance of the Sarbanes-Oxley governance and disclosure provisions (SOX) for US financial services firms. They show that financial institutions that complied with the disclosure and governance provisions (board independence, audit comittee independence, financial expertise, and financial reporting) improved their valuation. Furthermore, firms that adopted the SOX' provisions experienced lower unsystematic risk in the long-run. Board indepedence and information credibility (monitoring) strongly reduces overall and specific bank risks. In another US study, Pathan (2009) among other findings reveals that, independent directors reduce bank risk-taking as they pay more attention to reducing potentially loss-making investments which could spoil their reputation. This finding implies that independent board members are more sensitive to regulatory compliance in issues related to bank risk-taking.

In addition to provisions fostering board independence, other studies reveal that regulatory provisions on risk management improve bank stability. Ellul and Yerramilli (2013) construct a risk management index for US bank holding companies (BHC) from their 
regulatory filings on risk management. They find that BHCs with independent risk management were associated with lower risks (lower non-performing loans) during the crisis period. Lingel and Sheedy (2012) obtain similar results for those banks that established a risk management officer in senior management during the financial crisis period.

International regulators have also added to the roles that boards can play in mitigating excessive risk-taking by banks. The Bank for International Settlement (BIS) published a best practices code emphasizing the need to have more independent board members for exercising sound judgment without management influence. In addition, BIS requires more financial experts in boards and a better understanding of the bank's risky activities (BCBS, 2006). The Basel Committee on Banking Supervision (BCBS) also underlines the importance of boards in protecting the interest of shareholders, depositors and other relevant stakeholders. BCBS recommends to establishing a majority of independent and competent directors for improving risk management and to upgrade the role of the Chief Risk Officer (BCBS, 2010). These reports suggest that bank governance should not only focus on shareholders' wealth-maximizing activities but should also explicitly address risk-taking. We expect that banks comply with those recommendations from regulatory bodies in a similar way as they comply to other regulations. Accordingly, we hypothesize that banks are more likely to improve their own corporate governance if national governance codes published by central banks are in place. We also hypothesize that compliance with the central bank's recommandations by adjusting internal governance increases bank stability.

\subsection{The link between institutional development and bank stability}

There is a growing literature exploring the question of how the institutions in a country affect bank stability. The law and finance literature emphasizes the importance of legal origin and the institutional environment for bank behavior (LaPorta et al., 1998; Levine, 2005). Banks operating in legal systems with strong loan contract enforcement and well-developed information sharing on borrowers are associated with higher lending (Demirgüç-Kunt \& Detragiache, 2002). Micro-level bank evidence confirms this finding. Houston et al. (2010) show that banks operating in environments with better creditor rights are prepared to take on more lending risk as probabilities of defaults are reduced. Similar evidence is reported in Cole and Turk-Ariss (2013). They show that banks in commonlaw countries have higher exposure to loan risks than banks in civil-law countries, and that creditors are better protected under common-law. In contrast, banks operating in poor institutional environments tend to avoid high, poorly protected risk exposure and to lend only cautiously. 
Haselmann and Wachtel (2010) examine transition countries. They report that banks lend to Small and Medium Enterprises (SMEs) in favorable environments, but in unfavorable environments prefer to lend only to large firms and government agencies. Fang et al. (2014) study how institutional reforms in transitional economies influence bank stability. They find that bank stability increases only if countries improve their legal institutions and conduct reforms in both the banking sector and other industries. Berger and Udell (2006) also report in their study that legal and information infrastructures support banks' lending technologies to offer loans to SMEs.

In African countries banks respond to poor institutional environments by lending less to private sector and only investing in government securities (Beck \& Cull, 2014; Honohan \& Beck, 2007). Honohan and Beck (2007) note that, compared to other parts of the world, African countries have few credit bureaus and registries which makes it difficult for banks to obtain information on the borrowers. They also note that there are often difficulties in enforcing contracts. Private defaults and non-performing loan rates are higher given costly screening and weak contract enforcement in those countries. Weak corporate governance and legal systems in combination with poor contract enforcement render reforms focusing on bank stability ineffective in African countries (Cull \& Peria, 2012). We therefore expect that African banks show a higher stability if their home-countries possess strong legal systems and institutions. Compliance with the central bank's recommandations is expected to increase bank stability. Therefore, we hypothesize that publication of national governance codes is the mediating factor that links the home countries legal systems and institutions to bank governance and stability.

\subsection{The link of legal systems and institutions with code introduction}

National corporate governance reforms do not unfold in a vacuum rather they are a reflection of the country's legal system and its historical development. LaPorta et al. (1998) emphasize that legal origins affect corporate governance through rules that protect investors against exploitation by managers and inside owners. They argue that investor protection is higher in common law countries because of specific shareholder rights. Investor protection is beneficial for firm performance (La Porta, Lopez-De-Silanes, \& Shleifer, 2002).

In African countries, laws and regulations are drafted according to legal traditions that are, for the most part, inherited from former colonial rulers (Osemeke \& Adegbite, 2016). For instance, previous evidence shows that, despite corporate governance reforms in most African countries, the pace in launching new governance rules differs across countries. The codes' introduction suffers in particular from weak institutional environment fostering corruption (Kaufmann, Kraay, \& Mastruzzi, 2009; Okike, 2007; Wanyama et 
al., 2009), as well as from weak enforcement of laws (Okpara, 2011). Accordingly, we propose that the legal system developed during colonial occupation explains differences in launching bank-specific national corporate governance codes. Institutions that emerge from these legal systems might constrain or support countries in this respect.

\section{Data and Methodology}

\subsection{Data sources}

Data for this study are obtained from various sources. Data for bank performance and resilience are collected from the Bankscope database. Data on bank governance and ownership are obtained from Bankscope and, in addition, are hand collected from the banks' annual reports. Information about corporate governance codes is collected from the countries' central banks. Data on creditor and investor protections, macro-economic indicators as well as country-level governance indicators are all collected from the World Bank (Doing Business Reports, World Development Indicators) and the Kaufmann and Kraay (2008)' World Governance indicators (WGI). Data pertaining to legal origins are obtained from LaPorta et al. (1998). Table 1 summarizes the list of variables, their definitions and sources.

[Table 1 here]

\subsection{Sample description}

Bank and country data are matched to investigate the relationship between institutions/legal systems and publication of central corporate governance codes on the one hand, and code publication and bank governance and stability on the other hand. After excluding missing observations, the final panel sample includes 2,375 bank-year observations for 216 commercial banks across 44 African countries from 2005 to 2015.

\subsubsection{Measurement of banks' corporate governance}

We construct indexes of bank governance indicators that enable us to test whether banks do comply with the published corporate governance recommendations. Bank governance is measured by board size, independence, CEO duality, share of women in the board and disclosure of information related to executive remuneration. We follow previous studies in constructing the indicators of bank governance (Adams \& Mehran, 2003; Andres, Romero-Merino, Santamaría, \& Vallelado, 2012; Pathan, 2009) and bank disclosure measures (Song \& Li, 2012). Board size is defined by the number of board members in each 
bank. The share of independent non-executive directors in the board is measured by the variable Independ. Independent directors are defined as those that do not hold an executive position in the company and who do not have a stake in the bank. CEO duality is a dummy variable that takes the value of 1 if the Chief Executive Officer (CEO) is the chairperson of the board of directors of the same bank and 0 otherwise. The variable Sharewomen represents the share of women board members relative to the entire board of each bank. UsingBig4 is a dummy variable taking the value of 1 if a bank is audited by Deloitte, Ernst \& Young, KPMG or PricewaterhouseCoopers and 0 otherwise. Disclosure is a dummy variable taking the value of 1 if a bank discloses the directors' salaries in its annual reports and 0 otherwise.

\subsubsection{Measurement of bank resilience and performance}

The main indicator for bank resilience (or risk-taking) is the Z-score

$$
\text { Z-score }=\frac{R O A+\text { capital ratio }}{\sigma(R O A)}
$$

where $R O A$ is the return on assets, capital ratio is equity to total assets and $\sigma(R O A)$ is the standard deviation of $R O A$. The Z-score indicates how many standard deviation of $R O A$ the bank is away from zero bank capital and, thus, from bankruptcy. A higher Zscore signals that the bank is more stable and the probability of bankruptcy is low. Two alternative operationalizations of Z-score computation are used. The first one measures bank $R O A$ stability $\sigma(R O A)$ as constant standard deviation over the period in which the

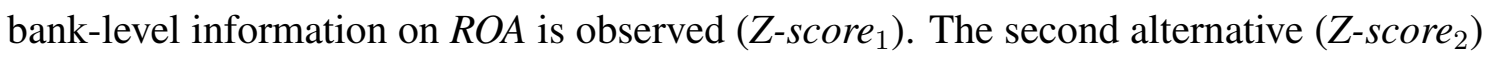
is calculated on a rolling-window basis (Beck, De Jonghe, \& Schepens, 2013; Goetz, 2017), only the current and previous three years are used for computing $\sigma(R O A)$. Zscore $_{2}$ is used as a robustness check to see whether obtained results are similar to those based on Z-score ${ }_{1}$.

Another resilience indicator is the ratio of nonperforming loans (NPL ratio). NPLs are loans not served by the customer (principal and interest payment) over a long period contrary to the terms and conditions of the loan contract. Thus, it also indicates the bank's success in screening and monitoring clients. Bank performance is measured using two ratios that are previously used in other studies (Adams \& Mehran, 2003; De Andres $\&$ Vallelado, 2008). These include the Return on Average Assets (ROAA) and the Return on Average Equity (ROAE). ROAA is the after tax net income (profits) divided by average total assets. It measures the extent to which the bank's management is able to generate profits from the use of its assets. ROAE indicates how effectively shareholder's funds are being used by the management of the company. It is obtained by dividing net income 
available to common stockholders by common equity.

\subsubsection{Measurement of corporate governance reforms, institutions and legal systems}

Corporate governance reforms are proxied by the publication of a corporate governance code for the banking sector in a specific country. The variable CGcode takes the value of 1 in the year and following years when a country introduces such governance regulation for banks and is 0 otherwise. Institutions are captured by two different sets of indicators. The first one reflects the Kaufmann and Kraay (2008)' index of countries' institutional quality measured by (1) Control of corruption, (2) Rule of Law, (3) Political stability, (4) Governance effectiveness, (5) Regulatory quality, and (6) Voice and accountability. The respective values range from -2.5 (weak) to +2.5 (strong institutional performance).

The second set consists of variables from the WorldBank doing business reports reflecting both investor and creditor protection. Extent of director liability index, Ease of shareholder suits index, and Strengths of investor protection index refer to minority investors. These variables range from 1 to 10, where 1 represents weak investor protection rights and 10 the highest level. The variable Enforcing contracts represents creditor rights. It indicates the average number of days it takes to enforce credit contracts in a country.

Finally, the legal system is measured using the Legal family of origin classification (LaPorta et al., 1998; Shleifer \& Vishny, 1997). In African countries only two legal origin are present: civil law legal family and common-law tradition. Countries that were colonized by Britain belong to the common-law tradition and those colonized by either France, Germany, Italy or Portugal are classified as civil-law countries. A dummy variable with a value of 0 indicates that the banks are located in a civil-law country, and 1 if the bank belongs to a common-law country. Table 1 provides a description of all variables.

\subsubsection{Bank-level and macro-economic control variables}

Two variables are used to control for bank specific characteristics. First, firm size is measured by total assets at the end of each fiscal year from 2005 to 2015 (Logtotalassets). Second, we control for bank ownership. The variable Percentage of ownership of the controlling shareholder measures ownership concentration. We also account for specific block-holder groups with more than or equal to $10 \%$ of total ownership: the government (Government ownership) and institutional owners (Institutional ownership).

In line with the existing literature, we control for inflation (Inflation) because it is likely to affect the financial system's stability. In addition, we use the GDP per capita (LogGDPperCapita) to account for differences in the countries' economic development. Finally, the Growth rate controls for business cycles. The macro data are from the World Bank Development Indicators for the period 2005-2015. 


\section{Empirical analysis}

\subsection{Descriptive results}

Table 2 reports descriptive statistics. Banks have on average nine members on their board. Five of the board members are, on average, independent non-executive directors, the rest are inside directors. Female directors comprise only $11 \%$ of the board for our entire sample. About $95 \%$ of banks in the sample have chairpersons with no dual CEO appointment. About 75\% use either Deloitte, Ernst \& Young, KPMG or PricewaterhouseCoopers as their auditors. About $16 \%$ disclose information on directors' remuneration in their annual reports.

\section{[Table 2 here]}

A majority of the banks are closely-held as proxied by the total percentage owned by the first largest shareholder(s) (68\%). About $80 \%$ of the banks are controlled by institutional investors, while $9.2 \%$ have governments as their controlling owners. The average Z-score is $17.33\left(\right.$ Z-score $\left._{1}\right)$ for the entire period, and $21.65(Z$-score 2$)$ when computed using a rolling window for the current and previous three years. The average return on assets ratio $(R O A A)$ is $1.90 \%$, and the average return on equity ratio ratio $(R O A E)$ is $15 \%$. Nonperforming loans account for $7.6 \%$ of total loans.

Table 3 reports descriptives for the country-level variables. On average, more than half of the countries ( 24 out of 44 ) have introduced a specific corporate governance reform during the period 2005-2015. About $61 \%$ of the countries belong to the civil-law Family while remaining countries belong to the common-law tradition (mean=0.391). The average annual growth rate is $4.6 \%$ and average annual inflation is $7.2 \%$.

\section{[Table 3 here]}

Table 4 reports the means of both regressors of interest and control variables by legal origin. On average, countries from the common-law tradition have published bank-specific corporate governance codes more often (55\%) compared to those from civil-law traditions (28\%). Banks from common-law countries that published codes are superior to their peers from the civil-law countries in following the codes' recommendations and in adjusting bank-internal corporate governance. Banks from common-law countries have on average larger bank boards with higher proportions of independent directors and more women on boards as well as lower levels of CEO dualities. In addition, common-law banks disclose their directors' pay and are more likely to use the Big4 as auditors. In terms of stability, banks in common-law countries have, on average, lower credit risk (lower NPL ratios), higher return on assets and a higher return on equity. However, the mean Z-scores are 
either higher of lower in common-law than in civil-law countries depending on how the scores are specified.

\section{[Table 4 here]}

Common-law countries show higher levels of institutional quality (control of corruption, rule of law, governance effectiveness, regulatory quality, and voice and accountability) and higher levels of shareholder protection and creditor rights. It takes fewer days for banks in common-law countries to enforce loan contracts. In terms of ownership structures, banks from civil-law countries are on average more closely-held while institutional owners are more dominant in banks from common-law countries. Government ownership of banks is less pronounced in common-law countries.

\subsection{Empirical model}

We use a difference-in-difference approach to examine how the introduction of corporate governance codes at the national level affects the individual bank's compliance and, subsequently, influences bank stability measured by two performance and two resilience indicators. The difference-in-difference approach allows us to compare the relative impact of corporate governance codes' (CGcode) before and after their introduction (Angrist \& Pischke, 2009). Diff-in-diff estimates can be obtained using a fixed effects panel model where the introduction of the code is modeled as the treatment dummy variable that takes a value of 0 before and a value of 1 in the year of introduction and the following years.

One could nevertheless argue that the introduction of the code is not an exogenous event but is itself dependent on a number of country-specific institutional characteristics and the country's level of economic development. To take these factors into consideration, we use a two-equation model,

$$
\begin{aligned}
\text { Bank governance/stability }_{i t}= & f\left(\mathrm{CGcode}_{k t}, \text { bank controls }_{i t}, \text { macro controls }_{k t}, \mu_{i}, \lambda_{t}\right) \\
& +\epsilon_{i t} \\
\text { CGcode }_{k t}= & f(\text { institutional characteristics } \\
k t & \left., \text { macro controls }_{k t}, \gamma_{t}\right) \\
& +\varepsilon_{k t}
\end{aligned}
$$

where $\mu_{i}$ are bank-specific fixed effects, $\lambda_{t}$ and $\gamma_{t}$ are year effects, $\epsilon_{i t}$ and $\varepsilon_{k t}$ are the error terms of Equations (1) and (2) that are allowed to be correlated. The first equation is a fixed effects model with year dummies that describes the individual bank's outcome in terms of governance and stability depending on a number of bank-specific controls and macro indicators. The second equation models the introduction of the corporate governance code (CGcode) in country $k$ and year $t$ in response to institutional characteristics 
(legal system, institutional development, investor and creditor protection). CGcode is a dummy variable equal to 1 for countries that published the code and 0 for non-publishing countries.

The control variables in Equation (1) are total assets and ownership indicators (ownership concentration as well as institutional and government ownership). The macroeconomic indicators in Equation (1) are the same as in Equation (2). Inflation is a proxy for the country's macro-economic stability and GDP per capita represents the level of economic development.

Two outcomes are of particular interest in response to the nation-wide introduction of governance codes. First, the degree to which banks comply with the published governance code and, second, the bank's subsequent performance and resilience. The individual bank's compliance with the code is captured by six main indicators, namely board size, board independence, women on board, CEO duality, disclosure of directors' remuneration and use of the Big Four as auditors. The indicators for the individual bank's resilience are Z-score and NPL ratio. Performance is measured by ROAA and ROAE.

As Equations (1) and (2) constitute a recursive system, we estimate them simultaneously by utilizing Roodman (2009)'s cmp procedure. The procedure can handle equations with differently scaled dependent variables. We combine the fixed effects equation with a probit model to examine how the publication of national bank-specific corporate governance codes affects bank outcomes.

\subsection{Code publishing and banks' corporate governance}

Table 5 provides the estimates for the impact of institutions on bank governance. The coefficient of the variable CGcode is statistically significant in all specifications implying that the publication of a corporate governance code by central banks supports banks in implementing own governance improvements. Columns 2 to 6 show that banks on average comply with the nation-wide code publication by increasing significantly the number of female directors and by increasing the proportion of non-executive independent directors in boards. There is a significant negative relationship between code publication and CEO duality implying that banks comply with code recommendations and reduce the chairperson's dual roles. Codes' publication also affects banks' use of one of the Big4 auditing companies. Banks from countries in which central banks published the code use the services of the Big4 auditors significantly more often than banks from non-publishing countries. In addition, banks significantly increase disclosure of directors' compensations in response to CGcode. There is, however, no relationship between code publication and banks' board size. 
[Table 5 here]

\subsection{Code publishing and banks' performance and resilience}

Table 6 reports the estimation results on the effects of code introduction on banks' performance and resilience. The coefficients for return on assets and return on equity are both positive and significant implying that codes publication increases banks operational performance $(R O A A)$ and accounting profitability (ROAE). The coefficients in Column 4 reveal that the introduction of corporate governance codes is associated with greater bank resilience, that is, a higher Z-score. Column 3 reports the coefficients for the alternative measure of bank resilience, the NPL ratio. Higher NPL ratios indicate more defaults on average among the customers of the bank. Contrary to our expectation, we find that loan defaults increase when central banks publish corporate governance recommendations. It might be caused by factors unrelated to the introduction of corporate governance code.

In contrast to the strong impact of code publication by central banks, the direct impact of bank-internal governance indicators on performance and resilience is weak. Only the coefficient on Logboardsize is positive and weakly significant in the ROAA-model indicating that banks with larger boards are associated with a higher accounting profitability. The coefficient of the indicators UsingBig4, CEO duality and Disclosure are significant only in one specification but the effect is non-robust across both Z-score models.

[Table 6 here]

\subsection{Determinants of code publishing}

The lower parts of of Tables 5 and 6 show that the incidence of a centrally published code mediating banks' governance reforms and stability is conditional on the quality of the countries' institutions. Table 5 reports that a common-law legal tradition increases the likelihood of a centrally published code, and via this channel, positively affects the number of female as well as independent directors and the likelihood of both disclosure of directors' pay and using the Big4 as auditors. The coefficients for this effect are positive and highly significant in all models. Political stability is the second positive and strongly significant driver of a centrally published code and mediator for an improved bank-internal governance. Domestic creditor and investor rights are the third positive driver. Specifically, the strengths of the investor protection index significantly increases the likelihood of nation-wide code introduction, and via this effect, promotes own governance reforms. In line with a priori expectations, we find that the lower the number of days for contract enforcement, the higher the likelihood of code introduction, most likely also reflecting a higher degree of institutional qualities in those countries. The institutional variable voice 
and accountability captures perceptions of a country's citizens to what extend they can participate in selecting the government and enjoy freedom of expression, freedom of association, and a free media. Contrary to expectations a low level of this indicator increases the likelihood of central banks' publishing a corporate governance code for banks. One explanation for this result could be that central banks feel in particular the need to have a stabilizing framework in place if the country's system of societal control is weak.

Table 6 shows that code publication occurs and, subsequently, improves banks' performance and resilience in those countries that are politically stable, are less corrupt and where investors are more strongly protected. Overall, the results reveal that country institutions and legal systems significantly affects the likelihood that corporate governance codes for banks are introduced which in turn affect banks' performance and resilience. The incidence of corporate governance reform and code publication at the country level acts as the mediating factor.

\subsection{Control variables}

Bank and macro controls have an impact on internal governance and stability. Closelyheld banks are associated with higher board share of both women and independent directors (Table 5). At the same time, these banks are associated with a higher likelihood of CEO duality and a lower likelihood of disclosure of directors pay. The government as controlling shareholder promotes CEO duality and independence of board members. Banks with controlling shareholders (Percentage of ownership) are associated with lower operating performance $(R O A A)$, lower profitability $(R O A E)$, increased credit risk (NPL ratio) and lower resilience ( Z-score1) (Table 6).

Larger banks are associated with larger boards, more information disclosures related to directors' pay and a higher proportion of women board members. Those banks are more profitable and have a lower insolvency risk. Specifically, a higher amount of bank assets is associated with higher operational performance $R O A A$, higher profits $R O A E$, a significantly lower NPL ratio and and a lower Z-score. With regard to the effects of macro economic variables, GDP per capita and inflation have no significant impact on resilience except in the robustness check specification.

\subsection{Robustness checks}

In our sample countries with a large number of banks are overrepresented. This may imply that the results in the lower parts of the Tables 5 and 6 (Equation 2) could be influenced by bank-level effects as well. To evaluate this possibility we separately measure the influence of different groups of country level variables on the introduction of corporate 
governance codes in each country using a probit model. In the first regression model, only minority investor protection rights variables are used as explanatory variables. The second regression model uses only macroeconomic variables as explanatory regressors. Here, we add the GDP growth rate to additionally control for business cyclicality. The third model includes country governance indicators as main regressors and the fourth specification combines the first three models. We include the legal family as the explanatory variable in all models.

Table 8 reports the results. The common-law countries have a significantly higher probability of publishing a corporate governance code. This result is robust across all model specifications. The large model in Column 4 confirms, by and large the results for Equation 2 in Table 5 and 6 . The economic and statistical significance of the explanatory variables, legal family of origin, strengths of investor protection index, enforcing contracts, political stability, voice and accountability is maintained in the single equation estimation. Therefore we can exclude that the findings in Table 5 and 6 are reversely influenced by bank-level effects.

[Table 8 here]

In the second robustness check we consider whether the results depend on how bank resilience is measured. We calculate the Z-score on a rolling-window basis $(Z$-score 2$)$ where for computing $\sigma(R O A)$ only the current and previous three years are used. Column (5) of Table 6 confirms basically the results of Column (4). However, despite a lower number of observations, the incidence of code publication has a stronger impact on bank resilience if the rolling window is used.

\subsection{Endogeneity concerns}

Potential endogeneity in the bank-level governance-performance relationship is a concern in many empirical studies as it could bias the estimates. To address this concern, many econometric studies have used instrumental variables. Note that in contrast to pure bank-level studies, our empirical approach is more robust with respect to endogeneity of corporate governance because the main variable of interest, introduction of CGcode, is determined at the country level while the outcome variables of interest, stability and performance, are determined at the bank-level. However, there exists a possibility that omitted variables at the country level might affect both the likelihood of introduction of a CGcode, and also the outcomes of certain bank-level variables. To address this issue, we are using two sets of country level variables that we assume to be exogenous to both a CGcode introduction and the bank-level outcomes: one set that is related to a country's institutional quality and another set of macro variables to describe the macro-economic 
conditions in a country. As we allow for correlation between both equations, our approach is similar to an endogenous treatment effect model where the treatment effect is the introduction of CGcode at country level. The fixed effects models for the bank-level outcome variables also avoids biased estimates due to omitted time invariant variables.

\section{Conclusions}

Using a sample of 216 banks from 44 African countries with data that covers the years 2005-2015, we investigate the effects of bank-specific corporate governance reforms at the country level and its impact bank governance and stability. We also explore whether this effect is conditioned by countries' institutions and legal systems.

Our main results suggest that banks improve their governance and stability after the introduction of the corporate governance codes' in their respective country. This evidence implies that a stronger bank internal governance through compliance with codes goes hand in hand with lower lending and other related bank risks. In addition, we find that introduction of corporate governance codes for banks is more likely in common-law countries than in Civil-law countries, thus the legal family of origin matters. Also, mediated via national governance reforms, good institutions at the country level improve banks' internal governance, increase return figures and strengthen resilience. Overall, our findings highlight the importance of codes introduction to promote bank stability in addition to other types of bank regulations. Our findings have important policy implications for African countries. Since banks are the major suppliers of credit in those economies, their stability determines also the prospects of economic growth and development.

This study is not without limitations. The number of observations in the estimation sample is smaller than in the original data set because a significant number of banks have missing observations on one or several important corporate governance indicators or on other variables. This might imply that the estimation sample is not representative for African banks in general but overrepresents the "better" banks. In general, it can be noted that many African banks do not provide sufficiently information about important characteristics of their corporate governance practices. Thus, introduction of and compliance with corporate governance code remains an important topic for African banks not only from a regulatory perspective. It also deserves more attention in future research. 


\section{References}

Adams, R. B., \& Mehran, H. (2003). Is corporate governance different for bank holding companies? Economic Policy Review, 9(1), 20. Retrieved from https:// www.newyorkfed.org/medialibrary/media/research/epr/03v09n1/0304adam.html

Akhigbe, A., \& Martin, A. D. (2006). Valuation impact of Sarbanes-Oxley: Evidence from disclosure and governance within the financial services industry. Journal of Banking \& Finance, 30(3), 989-1006.

Akhigbe, A., \& Martin, A. D. (2008). Influence of disclosure and governance on risk of US financial services firms following Sarbanes-Oxley. Journal of Banking \& Finance, 32(10), 2124-2135.

Andres, P., Romero-Merino, M. E., Santamaría, M., \& Vallelado, E. (2012). Board determinants in banking industry. an international perspective. Managerial and Decision Economics, , 33(3), 147-158. doi: https://doi.org/10.1002/mde.2541

Andrianova, S., Baltagi, B., Demetriades, P., \& Fielding, D. (2015). Why do African banks lend so little? Oxford Bulletin of Economics and Statistics, 77(3), 339-359.

Anginer, D., Demirguc-Kunt, A., \& Zhu, M. (2014). How does deposit insurance affect bank risk? Evidence from the recent crisis. Journal of Banking \& Finance, 48, 312-321.

Angrist, J. D., \& Pischke, J.-S. (2009). Mostly Harmless Econometrics: An Empiricist's Companion (No. 8769). Princeton University Press.

Ashraf, B. N. (2017). Political institutions and bank risk-taking behavior. Journal of Financial Stability, 29, 13-35.

Barth, J. R., Caprio Jr, G., \& Ross, L. (2004). Bank regulation and supervision: What works best? Journal of Financial Intermediation, 13, 205-248. doi: 10.1016/ j.jfi.2003.06.002

BCBS. (2006). Enhancing corporate governance for banking organisations (Tech. Rep.). Bank for International Settlement. Retrieved from https://www.bis.org/publ/ bcbs122.pdf

BCBS. (2010). Principles for enhancing corporate governance (Tech. Rep.). Bank for International Settlement. Retrieved from https://www.bis.org/publ/bcbs168.pdf

Beck, T., \& Cull, R. (2014). Banking in Africa. In The Oxford handbook of banking, second edition.

Beck, T., De Jonghe, O., \& Schepens, G. (2013). Bank competition and stability: crosscountry heterogeneity. Journal of Financial Intermediation, 22(2), 218-244.

Beck, T., Maimbo, S. M., Faye, I., \& Triki, T. (2011). Financing Africa: Through the crisis and beyond. World bank.

Berger, A. N., \& Udell, G. F. (2006). A more complete conceptual framework for SME 
finance. Journal of Banking \& Finance, 30(11), 2945-2966.

Cole, R., \& Turk-Ariss, R. (2013). Legal origin, creditor protection and bank lending around the world. Retrieved from https://ssrn.com/abstract=997582orhttp://dx.doi .org/10.2139/ssrn.997582

Cull, R., \& Peria, M. M. (2012). Foreign bank participation in developing countries. In The Evidence and Impact of Financial Globalization IMF.

De Andres, P., \& Vallelado, E. (2008). Corporate governance in banking: The role of the board of directors. Journal of Banking \& Finance, 32(12), 2570-2580.

Demirgüiç-Kunt, A., \& Detragiache, E. (2002). Does deposit insurance increase banking system stability? An empirical investigation. Journal of Monetary Economics, 49(7), 1373-1406.

Ellul, A., \& Yerramilli, V. (2013). Stronger risk controls, lower risk: Evidence from us bank holding companies. The Journal of Finance, 68(5), 1757-1803.

Essid, B. Y. . P. D., Z. (2014). Institutional quality and bank instability: cross-countries evidence in emerging countries. (Tech. Rep. No. MPRA Paper 56251). University Library of Munich, Germany.: University Library of Munich,. Retrieved from https://ideas.repec.org/p/pra/mprapa/56251.html

Fang, Y., Hasan, I., \& Fang, Y. (2014). Institutional development and bank stability: Evidence from transition countries. Journal of Banking \& Finance, 39, 160-175. Retrieved from http://dx.doi.org/10.1016/j.jbankfin.2013.11.003 doi: http://dx.doi .org/10.1016/j.jbankfin.2013.11.003

Goetz, M. R. (2017). Competition and bank stability. Journal of Financial Intermediation, In press. doi: https://doi.org/10.1016/j.jfi.2017.06.001

Haselmann, R., \& Wachtel, P. (2010). Institutions and bank behavior: Legal environment, legal perception, and the composition of bank lending. Journal of Money, Credit and Banking, 42(5).

Honohan, P., \& Beck, T. (2007). Making finance work for Africa. World Bank Publications.

Houston, J. F., Lin, C., Lin, P., \& Ma, Y. (2010). Creditor rights, information sharing, and bank risk taking. Journal of Financial Economics, 96(3), 485-512.

Kaufmann, D., \& Kraay, A. (2008). Governance indicators: Where are we, where should we be going? Oxford University Press, 23, 1-30. doi: doi;10.1093/wbro/lkm012

Kaufmann, D., Kraay, A., \& Mastruzzi, M. (2009). Governance matters 2009: learning from over a decade of the worldwide governance indicators. The Brookings Institution, Washington, DC. Available: http://www. brookings. edu/opinions.

Klomp, J., \& de Haan, J. (2015). Bank regulation and financial fragility in developing countries: Does bank structure matter? Review of Development Finance, 5, 82-90. 
doi: http://dx.doi.org/10.1016/j.rdf.2015.11.001

Laeven, L., \& Levine, R. (2009). Bank governance, regulation and risk-taking. Journal of Financial Economics, 93, 259-275. doi: doi:10.1016/j.jfineco.2008.09.003

LaPorta, R., de Silanes, F. L., Shleifer, A., \& Vishny, R. W. (1998). Law and finance. Journal of Political Economy, 106(2), 1113-1155.

La Porta, R., Lopez-De-Silanes, F., \& Shleifer, A. (2002). Government ownership of banks. The Journal of Finance, 57(1), 265-301. Retrieved from http://dx.doi.org/ 10.1111/1540-6261.00422 doi: 10.1111/1540-6261.00422

Levine, R. (2005). Chapter 12 finance and growth: Theory and evidence. In P. Aghion \& S. N. Durlauf (Eds.), (Vol. 1, p. 865 - 934). Elsevier. Retrieved from http:// www.sciencedirect.com/science/article/pii/S1574068405010129 doi: https://doi .org/10.1016/S1574-0684(05)01012-9

Lingel, A., \& Sheedy, E. (2012). The influence of risk governance on risk outcomesinternational evidence. (No.37). Retrieved from http://dx.doi.org/10.2139/ssrn .2187116

Nana, P. N., \& Samson, L. (2014). Why are banks in Africa hoarding reserves? An empirical investigation of the precautionary motive. Review of Development Finance, 4(1), 29-37.

Okike, E. N. M. (2007). Corporate governance in Nigeria: The status quo. Corporate Governance: An International Review, 15, 173-193.

Okpara, J. O. (2011). Corporate governance in a developing economy: barriers, issues, and implications for firms. Corporate Governance: The International Journal of Business in Society, , 11(2,), 184-199. Retrieved from https://doi.org/10.1108/ 14720701111121056 doi: https://doi.org/10.1108/14720701111121056

Osemeke, L., \& Adegbite, E. (2016). Regulatory multiplicity and conflict: Towards a combined code on corporate governance in Nigeria. Journal of Business Ethics, 133, 431-451. doi: DOI10.1007/s10551-014-2405-3

Pathan, S. (2009). Strong boards, CEO power and bank risk-taking. Journal of Banking \& Finance, , 33(7,), 1340-1350. Retrieved from https://doi.org/10.1016/j.jbankfin .2009.02.001

Qian, X., Cao, T., \& Cao, C. (2018). Institutional environment and bank loans: Evidence from 25 developing countries. Corporate Governance: An International Review, 26(2), 84-96.

Shleifer, A., \& Vishny, R. W. (1997). A survey of corporate governance. The Journal of Finance, 52(2), 737-783. Retrieved from http://dx.doi.org/10.1111/j.1540-6261 .1997.tb04820.x doi: 10.1111/j.1540-6261.1997.tb04820.x

Song, F. M., \& Li, L. (2012, April). Bank Governance: Concepts and Measure- 
ments. In Research Handbook on International Banking and Governance (pp. 1741). Edward Elgar Publishing. Retrieved from https://www.elgaronline.com/view/ 9781849802932.00010.xml(application/pdf)

Triki, T., Kouki, I., Dhaou, M. B., \& Calice, P. (2017). Bank regulation and efficiency: What works for Africa? Research in International Business and Finance, 39, 183205.

Wanyama, S., Burton, B., \& Helliar, C. (2009). Frameworks underpinning corporate governance: Evidence on Ugandan perceptions. Corporate Governance: An International Review, 17(2), 159-175. doi: doi:10.1111/j.1467-8683.2009.00730.x

Zhang, J., Wang, P., \& Qu, B. (2012). Bank risk taking, efficiency, and law enforcement: Evidence from Chinese city commercial banks. China Economic Review, 23(2), 284-295. Retrieved from https://doi.org/10.1016/j.chieco.2011.12.001

\section{Appendix}

\section{Tables}

Table 1: Description of variables used in the analysis

\begin{tabular}{|c|c|c|}
\hline Variable & Descriptions & Source \\
\hline Board size & Board size is the number of board members in each bank. & (b) \\
\hline CEO duality & $\begin{array}{l}\text { A dummy variable that takes the value of } 1 \text { if the bank CEO is a } \\
\text { chairperson of the board of the same bank and } 0 \text { otherwise }\end{array}$ & (b) \\
\hline CGcode & $\begin{array}{l}\text { Dummy variable that takes the value of } 1 \text { if the country's central } \\
\text { bank had published a bank specific corporate governance code in } \\
\text { a particular year and } 0 \text { otherwise }\end{array}$ & (d2) \\
\hline Control of corruption & $\begin{array}{l}\text { Estimate of control of corruption from }-2.5 \text { (weak) to } 2.5 \text { (strong) } \\
\text { to measure the extent to which power could be exercised not for } \\
\text { public gain. }\end{array}$ & (c2) \\
\hline Disclosure & $\begin{array}{l}\text { Dummy variable taking the value of } 1 \text { if a bank discloses direc- } \\
\text { tors' compensation and pay in its annual reports and } 0 \text { otherwise. }\end{array}$ & (b) \\
\hline $\begin{array}{l}\text { Ease of shareholder suits } \\
\text { index }\end{array}$ & $\begin{array}{l}\text { Measured from } 0-10 \text { for which } 0 \text { represents low index and } 10 \text { the } \\
\text { highest.It captures ease with which minority shareholders can ac- } \\
\text { cess internal corporate documents to use during trials and whether } \\
\text { they can recover legal expenses from their companies }\end{array}$ & (c3) \\
\hline Enforcing contracts & $\begin{array}{l}\text { Measured in number of days for the time it takes to enforce con- } \\
\text { tracts. }\end{array}$ & (c3) \\
\hline $\begin{array}{l}\text { Extent of director liability } \\
\text { index }\end{array}$ & $\begin{array}{l}\text { Captures the extent to which the minority shareholders can sue } \\
\text { and hold directors accountable for related party transactions and } \\
\text { if they can get legal remedies. Measured on a scale of } 0-10 \text {. } 0 \\
\text { represents low director liability and } 10 \text { the highest. }\end{array}$ & (c3) \\
\hline Governance effectiveness & $\begin{array}{l}\text { Estimate of governance from }-2.5 \text { (weak) to } 2.5 \text { (strong) to mea- } \\
\text { sure the quality of policies, services, independence and govern- } \\
\text { ments'commitments to quality policies. }\end{array}$ & (c2) \\
\hline
\end{tabular}




\begin{tabular}{|c|c|c|}
\hline Variable & Descriptions & Source \\
\hline Government ownership & $\begin{array}{l}\text { A dummy variable which takes the value of } 1 \text { if the state is the } \\
\text { largest shareholder and } 0 \text { otherwise. }\end{array}$ & (b) \\
\hline Growth rate & Annual economic growth rate in percentage terms & (c1) \\
\hline Independ & $\begin{array}{l}\text { Share of non-executive independent directors in each bank to total } \\
\text { board size. }\end{array}$ & (b) \\
\hline Inflation & Expressed in percentage terms. & (c1) \\
\hline Institutional ownership & $\begin{array}{l}\text { A dummy variable which takes the value of } 1 \text { if institutional in- } \\
\text { vestors are the largest shareholders and } 0 \text { otherwise. }\end{array}$ & (b) \\
\hline Legal family of origin & $\begin{array}{l}\text { Dummy variable that equals } 0 \text { if banks belong to civil law legal } \\
\text { countries and } 1 \text { for banks that belong to common law countries. }\end{array}$ & $(\mathrm{d} 1)$ \\
\hline LogGDPperCapita & Logarithm of GDP per capita expressed in US Dollars. & (c1) \\
\hline Logtotalassets & $\begin{array}{l}\text { Natural logarithm of a bank's total assets.It measures the size of } \\
\text { the bank }\end{array}$ & (a) \\
\hline NPL ratio & $\begin{array}{l}\text { The ratio of non performing loans to total loans. It measured as } \\
\text { (NPLs)/Gross loans. }\end{array}$ & (a) \\
\hline Percentage of ownership & $\begin{array}{l}\text { Measured as percentage of shares owned by the controlling share- } \\
\text { holder(s). }\end{array}$ & (b) \\
\hline Political stability & $\begin{array}{l}\text { Measured on the scale from }-2.5 \text { (unstable) to } 2.5 \text { (highly stable) } \\
\text { to capture peoples' perception of the likelihood that governments } \\
\text { will be destabilized or overthrown through violent means. }\end{array}$ & (c2) \\
\hline Requlatory quality & $\begin{array}{l}\text { Measured on the scale from }-2.5 \text { (low ) to } 2.5 \text { (high). It measures } \\
\text { governments' capacity to design and implement policies which } \\
\text { are pro-private development. }\end{array}$ & (c2) \\
\hline ROAA & $\begin{array}{l}\text { After tax net income (profits) divided by average total assets of } \\
\text { bank. }\end{array}$ & (a) \\
\hline ROAE & $\begin{array}{l}\text { Net income available to common stockholders divided by com- } \\
\text { mon equity. }\end{array}$ & (a) \\
\hline Rule of Law & $\begin{array}{l}\text { Measured on the scale from }-2.5 \text { (weak ) to } 2.5 \text { (strong) to cap- } \\
\text { ture the extent to which leaders respect institutions and the rules } \\
\text { governing the society. }\end{array}$ & (c2) \\
\hline Sharewomen & $\begin{array}{l}\text { Measures the share of women sitting on the board to the entire } \\
\text { bank board. }\end{array}$ & (b) \\
\hline $\begin{array}{l}\text { Strengths of investor pro- } \\
\text { tection index }\end{array}$ & $\begin{array}{l}\text { This is average of conflict of interest regulation index and extent } \\
\text { of shareholder governance index and is measured on a scale of } \\
0-10 \text { for which } 0 \text { represents weak or no investor protection and } \\
10 \text { the greatest investor protection. }\end{array}$ & (c3) \\
\hline UsingBig4 & $\begin{array}{l}\text { Dummy variable taking the value of } 1 \text { if a bank is audited by the } \\
\text { big } 4 \text { auditing companies (Deloitte \& Touché, KPMG, Ernest \& } \\
\text { Young, Price waters cooper house) and } 0 \text { otherwise. }\end{array}$ & (b) \\
\hline Voice and accountability & $\begin{array}{l}\text { Measured on the scale from }-2.5 \text { (weak ) to } 2.5 \text { (strong) to capture } \\
\text { the extent of citizens' participation in electing their governments } \\
\text { and freedoms-of expression, association and media freedom. }\end{array}$ & (c2) \\
\hline Z-score $_{1,2}$ & $\begin{array}{l}\text { Return on Assets + capital ratio (Equity/Total assets) / Standard } \\
\text { deviation of Return on Assets. Z-scores is an indicator of bank } \\
\text { stability }\end{array}$ & (a) \\
\hline
\end{tabular}


...continued

Variable

Descriptions

Source

Notes: Sources (a) Bankscope (BvD) database; (b) Hand collected in the banks' annual reports + Bankscope; (c1) World bank Development Indicators (WDI); (c2) World Bank Governance Indicators (WGI); (c3) World Bank-Doing Business report; (d1) LaPorta et al. (1998); (d2) Hand search from Countries' central banks

Table 2: Descriptive statistics at bank-level

\begin{tabular}{|c|c|c|c|c|c|}
\hline Variable & Obs & Mean & Std. Dev. & Min & Max \\
\hline Board size & 1,310 & 9.468 & 3.487 & 3 & 23 \\
\hline CEO duality & 1,291 & 0.048 & 0.214 & 0 & 1 \\
\hline Disclosure & 1,312 & 0.162 & 0.368 & 0 & 1 \\
\hline Government ownership & 1,310 & 0.092 & 0.290 & 0 & 1 \\
\hline Independent & 1,222 & 0.534 & 0.251 & 0 & 1 \\
\hline Institutional ownership & 1,313 & 0.800 & 0.400 & 0 & 1 \\
\hline Logtotalassets & 1,795 & 13.02 & 1.977 & 2.283 & 18.67 \\
\hline NPL ratio $(\%)$ & 1,167 & 7.579 & 9.551 & 0 & 93.1 \\
\hline Percentage of ownership (\%) & 1,297 & 68.06 & 31.59 & 1 & 100 \\
\hline $\operatorname{ROAA}^{a}(\%)$ & 1,795 & 1.827 & 4.232 & -54.7 & 41.3 \\
\hline $\operatorname{ROAE}^{a}(\%)$ & 1,791 & 15.66 & 28.61 & -438.6 & 536.4 \\
\hline Sharewomen & 1,138 & 0.109 & 0.107 & 0 & 0.556 \\
\hline UsingBig4 & 1,312 & 0.753 & 0.431 & 0 & 1 \\
\hline Z-score $_{1}$ & 2,328 & 17.33 & 24.75 & -5.615 & 466.5 \\
\hline Z-score $_{2}$ & 1,162 & 21.65 & 22.24 & -3.72 & 253.7 \\
\hline
\end{tabular}

Notes: Z-score ${ }_{1}$ measured based bank-specific time-invariant $\sigma(R O A), \mathrm{Z}_{\text {-score }}$

measured based on rolling window $\sigma(R O A)$, see Section 3.2.2.

${ }^{a}$ trimmed as dependent variable in Table 6 at $1 \%$. 
Table 3: Institutional and economic variables at country-year level

\begin{tabular}{lrrrrr}
\hline Variable & Obs & Mean & Std. Dev. & Min & \multicolumn{1}{c}{ Max } \\
\hline CGcode & 467 & 0.409 & 0.492 & 0 & 1 \\
Control of corruption & 479 & -0.597 & 0.577 & -1.712 & 1.139 \\
Ease of shareholder suits index & 374 & 4.494 & 2.270 & 0 & 10 \\
Enforcing contracts (days) & 442 & 670.8 & 238.8 & 228 & 1300 \\
Extent of director liability index & 418 & 3.270 & 2.596 & 0 & 9 \\
Governance effectiveness & 478 & -0.687 & 0.594 & -2.171 & 1.036 \\
Growth rate (\%) & 476 & 4.620 & 5.783 & -62.1 & 22.6 \\
Inflation (\%) & 476 & 7.200 & 7.462 & -2.248 & 47.31 \\
Legal family of origin & 478 & 0.391 & 0.489 & 0 & 1 \\
LogGDPperCapita & 465 & 7.085 & 1.050 & 5.014 & 9.574 \\
Political stability & 478 & -0.533 & 0.854 & -2.687 & 1.183 \\
Regulatory quality & 478 & -0.591 & 0.574 & -2.237 & 1.123 \\
Rule of Law & 478 & -0.631 & 0.605 & -1.842 & 1.005 \\
Strengths of investor protection index & 374 & 4.189 & 1.488 & 1.7 & 8 \\
Voice and accountability & 477 & -0.591 & 0.679 & -1.936 & 0.970 \\
\hline
\end{tabular}

Note: ${ }^{1}$ Inflation rate winsorized at $1 \%$ due to extreme values. 
Table 4: Descriptive statistics by Legal family of origin

\begin{tabular}{|c|c|c|c|c|c|}
\hline Variable & Obs. & Civil-law & Common-law & Total & $t$-test \\
\hline Board size & 1,310 & 8.590 & 10.28 & 9.468 & $-9.06^{* * *}$ \\
\hline CEO duality & 1,291 & 0.099 & 0 & 0.048 & $8.60^{* * *}$ \\
\hline Cgcode & 467 & 0.320 & 0.557 & 0.409 & $-5.19^{* * *}$ \\
\hline Control of corruption & 478 & -0.712 & -0.417 & -0.596 & $-5.61^{* * *}$ \\
\hline Disclosure & 1,312 & 0.028 & 0.287 & 0.162 & $-13.5^{* * *}$ \\
\hline Ease of shareholder suits index & 374 & 3.388 & 6.303 & 4.495 & $-15.4^{* * *}$ \\
\hline Enforcing contracts & 439 & 721.1 & 598.4 & 673.9 & $5.45^{* * *}$ \\
\hline Extent of director liability index & 418 & 2.205 & 4.988 & 3.270 & $-12.5^{* * *}$ \\
\hline Governance effectiveness & 478 & -0.824 & -0.475 & -0.687 & $-6.54^{* * *}$ \\
\hline Government ownership & 1,310 & 0.120 & 0.066 & 0.092 & $3.38^{* * *}$ \\
\hline Growth rate $(\%)$ & 474 & 4.561 & 4.705 & 4.618 & -0.27 \\
\hline Indepedent & 1,222 & 0.478 & 0.581 & 0.534 & $-7.23^{* * *}$ \\
\hline Inflation (\%) & 474 & 5.790 & 9.449 & 7.218 & $-5.35^{* * *}$ \\
\hline Institutional ownership & 1,313 & 0.781 & 0.819 & 0.800 & $-1.70^{*}$ \\
\hline LogGDPpercapita & 462 & 7.038 & 7.151 & 7.084 & -1.14 \\
\hline Logtotalassets & 1,795 & 13.19 & 12.86 & 13.02 & $3.48^{* * *}$ \\
\hline NPL ratio $(\%)$ & 1,167 & 8.825 & 6.891 & 7.579 & $3.33^{* * *}$ \\
\hline Percentage of ownership & 1,297 & 69.06 & 67.03 & 68.02 & 1.16 \\
\hline Political stability & 478 & -0.700 & -0.273 & -0.533 & $-5.48^{* * *}$ \\
\hline Regulatory quality & 478 & -0.729 & -0.377 & -0.591 & $-6.85^{* * *}$ \\
\hline ROAA $(\%)$ & 1,791 & 1.321 & 2.291 & 1.827 & $-4.88^{* * *}$ \\
\hline ROAE (\%) & 1,138 & 15.29 & 16.00 & 15.66 & -0.52 \\
\hline Rule of law & 478 & -0.769 & -0.416 & -0.631 & $-6.49^{* * *}$ \\
\hline Sharewomen & 1,312 & 0.083 & 0.130 & 0.109 & $-7.58^{* * *}$ \\
\hline Strengths of investor protection index & 374 & 3.513 & 5.293 & 4.189 & $-13.8^{* * *}$ \\
\hline UsingBig4 & 1312 & 0.576 & 0.919 & 0.753 & $-15.6^{* * *}$ \\
\hline Voice and accountability & 477 & -0.782 & -0.295 & -0.591 & $-8.17^{* * *}$ \\
\hline Z-score $_{1}$ & 2,316 & 17.11 & 17.67 & 17.42 & -0.54 \\
\hline Z-score ${ }_{2}$ & 1,162 & 23.47 & 19.88 & 21.65 & $2.75^{* * *}$ \\
\hline
\end{tabular}

Notes: $t$-test on difference of means for bank-level and country-level variables. ${ }^{*} p<0.10,{ }^{* *} p<0.05$,

${ }^{* * *} p<0.01$. Fewer number of observations than previous Tables due to missing legal family of origin classifications. 
Table 5: Impact of CG code on bank-level CG indicators: CMP estimation of Equations (1) and (2)

\begin{tabular}{|c|c|c|c|c|c|c|}
\hline & $\begin{array}{c}(1) \\
\text { Logboard } \\
\text { size }\end{array}$ & $\begin{array}{c}(2) \\
\text { Using } \\
\text { Big4 }\end{array}$ & $\begin{array}{c}\text { (3) } \\
\text { CEO } \\
\text { duality }\end{array}$ & $\begin{array}{c}(4) \\
\text { Dis } \\
\text { closure }\end{array}$ & $\begin{array}{c}(5) \\
\text { Share } \\
\text { women }\end{array}$ & $\begin{array}{c}(6) \\
\text { In } \\
\text { depend }\end{array}$ \\
\hline \multicolumn{7}{|c|}{ Equation 1: Bank-level CG indicators } \\
\hline CGcode & $\begin{array}{c}-0.0560 \\
(-1.61)\end{array}$ & $\begin{array}{c}0.676^{* * *} \\
(5.32)\end{array}$ & $\begin{array}{c}-0.487^{* *} \\
(-2.35)\end{array}$ & $\begin{array}{c}0.811^{* * *} \\
(5.25)\end{array}$ & $\begin{array}{c}0.0692^{* * *} \\
(4.10)\end{array}$ & $\begin{array}{c}0.0614^{* *} \\
(2.57)\end{array}$ \\
\hline Percentage of ownership & $\begin{array}{c}0.0000142 \\
(0.02)\end{array}$ & $\begin{array}{c}0.00159 \\
(1.13)\end{array}$ & $\begin{array}{c}0.0109^{* * *} \\
(4.16)\end{array}$ & $\begin{array}{c}-0.00527^{* * *} \\
(-3.83)\end{array}$ & $\begin{array}{c}0.000445^{* * *} \\
(2.71)\end{array}$ & $\begin{array}{c}0.00160^{* * *} \\
(6.37)\end{array}$ \\
\hline Logtotalassets & $\begin{array}{c}0.0594^{* * *} \\
(4.53)\end{array}$ & $\begin{array}{c}-0.0184 \\
(-0.73)\end{array}$ & $\begin{array}{c}0.333^{* * *} \\
(6.38)\end{array}$ & $\begin{array}{c}0.145^{* * *} \\
(6.06)\end{array}$ & $\begin{array}{c}0.0155^{* * *} \\
(5.34)\end{array}$ & $\begin{array}{c}-0.00177 \\
(-0.41)\end{array}$ \\
\hline Institutional ownership & $\begin{array}{c}-0.404^{* * *} \\
(-3.74)\end{array}$ & $\begin{array}{c}0.540^{* * *} \\
(3.90)\end{array}$ & $\begin{array}{c}-0.586^{* * *} \\
(-2.82)\end{array}$ & $\begin{array}{c}0.292^{*} \\
(1.94)\end{array}$ & $\begin{array}{c}-0.00151 \\
(-0.08)\end{array}$ & $\begin{array}{c}0.0808^{* * *} \\
(3.10)\end{array}$ \\
\hline LogGDPperCapita & $\begin{array}{c}-0.0410 \\
(-1.04)\end{array}$ & $\begin{array}{c}0.418^{* * *} \\
(8.34)\end{array}$ & $\begin{array}{l}-0.150 \\
(-1.32)\end{array}$ & $\begin{array}{c}0.353^{* * *} \\
(6.65)\end{array}$ & $\begin{array}{c}-0.00240 \\
(-0.41)\end{array}$ & $\begin{array}{c}-0.0460^{* * *} \\
(-5.24)\end{array}$ \\
\hline Inflation & $\begin{array}{c}-0.000281 \\
(-0.20)\end{array}$ & $\begin{array}{c}0.0254^{* * *} \\
(2.99)\end{array}$ & $\begin{array}{c}-0.0251 \\
(-1.56)\end{array}$ & $\begin{array}{c}0.0210^{* *} \\
(2.08)\end{array}$ & $\begin{array}{c}0.00172^{*} \\
(1.67)\end{array}$ & $\begin{array}{c}0.00150 \\
(0.92)\end{array}$ \\
\hline Government ownership & - & $\begin{array}{c}-0.0279 \\
(-0.16)\end{array}$ & $\begin{array}{c}0.742^{* * *} \\
(3.27)\end{array}$ & $\begin{array}{l}-0.142 \\
(-0.69)\end{array}$ & $\begin{array}{c}0.00553 \\
(0.23)\end{array}$ & $\begin{array}{c}0.0678^{*} \\
(1.87)\end{array}$ \\
\hline Constant & $\begin{array}{c}2.380^{* * *} \\
(5.98)\end{array}$ & $\begin{array}{c}-3.149^{* * *} \\
(-7.31)\end{array}$ & $\begin{array}{c}-5.549^{* * *} \\
(-6.97)\end{array}$ & $\begin{array}{c}-6.295^{* * *} \\
(-12.64)\end{array}$ & $\begin{array}{c}-0.191^{* * *} \\
(-3.54)\end{array}$ & $\begin{array}{c}0.665^{* * *} \\
(8.55)\end{array}$ \\
\hline Bank-level fixed effects & yes & no & no & no & no & no \\
\hline Year effects & yes & yes & yes & yes & yes & yes \\
\hline Estimation method & FE panel & probit & probit & probit & tobit & tobit \\
\hline \multicolumn{7}{|c|}{ Equation 2: prob $($ CGcode $=1)$, probit model } \\
\hline Legal family of origin & $\begin{array}{c}1.282^{* * *} \\
(8.34)\end{array}$ & $\begin{array}{c}1.351^{* * *} \\
(8.58)\end{array}$ & $\begin{array}{c}1.381^{* * *} \\
(8.97)\end{array}$ & $\begin{array}{c}1.435^{* * *} \\
(10.02)\end{array}$ & $\begin{array}{c}1.332^{* * *} \\
(8.89)\end{array}$ & $\begin{array}{c}1.429^{* * *} \\
(9.12)\end{array}$ \\
\hline Control of corruption & $\begin{array}{l}0.289 \\
(1.62)\end{array}$ & $\begin{array}{c}0.342^{*} \\
(1.89)\end{array}$ & $\begin{array}{l}0.234 \\
(1.32)\end{array}$ & $\begin{array}{c}0.290^{*} \\
(1.71)\end{array}$ & $\begin{array}{c}0.367^{* *} \\
(2.14)\end{array}$ & $\begin{array}{l}0.221 \\
(1.26)\end{array}$ \\
\hline Governance effectiveness & $\begin{array}{l}0.281 \\
(1.31)\end{array}$ & $\begin{array}{c}0.195 \\
(0.90)\end{array}$ & $\begin{array}{c}0.480^{* *} \\
(2.25)\end{array}$ & $\begin{array}{l}0.320 \\
(1.59)\end{array}$ & $\begin{array}{l}0.140 \\
(0.67)\end{array}$ & $\begin{array}{l}0.329 \\
(1.55)\end{array}$ \\
\hline Political stability & $\begin{array}{c}0.557^{* * *} \\
(7.21)\end{array}$ & $\begin{array}{c}0.529^{* * *} \\
(6.74)\end{array}$ & $\begin{array}{c}0.582^{* * *} \\
(7.71)\end{array}$ & $\begin{array}{c}0.468^{* * *} \\
(6.29)\end{array}$ & $\begin{array}{c}0.576^{* * *} \\
(7.89)\end{array}$ & $\begin{array}{c}0.559^{* * *} \\
(7.44)\end{array}$ \\
\hline Regulatory quality & $\begin{array}{l}-0.292 \\
(-1.49)\end{array}$ & $\begin{array}{l}-0.268 \\
(-1.38)\end{array}$ & $\begin{array}{c}-0.566^{* * *} \\
(-2.88)\end{array}$ & $\begin{array}{l}-0.219 \\
(-1.21)\end{array}$ & $\begin{array}{l}-0.251 \\
(-1.32)\end{array}$ & $\begin{array}{l}-0.313 \\
(-1.62)\end{array}$ \\
\hline Voice and accountability & $\begin{array}{c}-2.082^{* * *} \\
(-11.00)\end{array}$ & $\begin{array}{c}-2.099^{* * *} \\
(-11.16)\end{array}$ & $\begin{array}{c}-2.096^{* * *} \\
(-11.08)\end{array}$ & $\begin{array}{c}-2.046^{* * *} \\
(-10.94)\end{array}$ & $\begin{array}{c}-2.074^{* * *} \\
(-11.35)\end{array}$ & $\begin{array}{c}-2.007^{* * *} \\
(-10.67)\end{array}$ \\
\hline LogGDPperCapita & $\begin{array}{c}-0.0219 \\
(-0.33)\end{array}$ & $\begin{array}{c}-0.00115 \\
(-0.02)\end{array}$ & $\begin{array}{c}-0.0368 \\
(-0.56)\end{array}$ & $\begin{array}{c}-0.0450 \\
(-0.74)\end{array}$ & $\begin{array}{c}-0.0497 \\
(-0.76)\end{array}$ & $\begin{array}{c}-0.00545 \\
(-0.08)\end{array}$ \\
\hline Inflation & $\begin{array}{c}0.00346 \\
(0.41)\end{array}$ & $\begin{array}{c}0.00307 \\
(0.37)\end{array}$ & $\begin{array}{c}0.00145 \\
(0.17)\end{array}$ & $\begin{array}{c}0.000181 \\
(0.08)\end{array}$ & $\begin{array}{c}0.00384 \\
(0.47)\end{array}$ & $\begin{array}{c}0.00249 \\
(0.30)\end{array}$ \\
\hline Enforcing contracts & $\begin{array}{c}-1.156^{* * *} \\
(-11.05)\end{array}$ & $\begin{array}{c}-1.158^{* * *} \\
(-11.21)\end{array}$ & $\begin{array}{c}-1.144^{* * *} \\
(-11.10)\end{array}$ & $\begin{array}{c}-1.118^{* * *} \\
(-11.32)\end{array}$ & $\begin{array}{c}-1.109^{* * *} \\
(-10.99)\end{array}$ & $\begin{array}{r}-1.083^{* * *} \\
(-10.30)\end{array}$ \\
\hline $\begin{array}{l}\text { Strengths of } \\
\text { investor protection index }\end{array}$ & $\begin{array}{c}0.319^{* * *} \\
(6.23)\end{array}$ & $\begin{array}{c}0.321^{* * *} \\
(6.25)\end{array}$ & $\begin{array}{c}0.351^{* * *} \\
(6.80)\end{array}$ & $\begin{array}{c}0.313^{* * *} \\
(6.25)\end{array}$ & $\begin{array}{c}0.350^{* * *} \\
(7.05)\end{array}$ & $\begin{array}{c}0.275^{* * *} \\
(5.28)\end{array}$ \\
\hline Constant & $\begin{array}{l}0.415 \\
(0.80)\end{array}$ & $\begin{array}{l}0.167 \\
(0.32)\end{array}$ & $\begin{array}{l}0.237 \\
(0.46)\end{array}$ & $\begin{array}{l}0.498 \\
(1.03)\end{array}$ & $\begin{array}{l}0.321 \\
(0.64)\end{array}$ & $\begin{array}{l}0.313 \\
(0.62)\end{array}$ \\
\hline
\end{tabular}


...continued

\begin{tabular}{lcccccc}
\hline & $\begin{array}{c}(1) \\
\text { Logboard } \\
\text { size }\end{array}$ & $\begin{array}{c}\text { Using } \\
\text { Big4 }\end{array}$ & $\begin{array}{c}\text { CEO } \\
\text { duality }\end{array}$ & $\begin{array}{c}\text { (4) } \\
\text { Dis } \\
\text { closure }\end{array}$ & $\begin{array}{c}\text { Share } \\
\text { women }\end{array}$ & $\begin{array}{c}\text { (6) } \\
\text { depend }\end{array}$ \\
\hline Year effects & yes & yes & yes & yes & yes & yes \\
\hline $\ln \sigma_{1}$ & $-2.054^{* * *}$ & - & - & - & $-1.863^{* * *}$ & $-1.381^{* * *}$ \\
& $(-96.31)$ & & & & $(-59.50)$ & $(-62.23)$ \\
\hline$\rho_{12}$ & 0.124 & $-0.214^{*}$ & $0.775^{* * *}$ & $-0.812^{* * *}$ & $-0.485^{* * *}$ & $-0.290^{* * *}$ \\
& $(0.56)$ & $(-1.91)$ & $(4.91)$ & $(-3.56)$ & $(-5.20)$ & $(-3.69)$ \\
\hline$N$ system & 1993 & 1993 & 1964 & 1993 & 1955 & 1977 \\
$N$ eq. 1 & 1237 & 1239 & 1194 & 1239 & 1070 & 1155 \\
$N$ eq. 2 & 1709 & 1709 & 1709 & 1709 & 1709 & 1709 \\
\hline
\end{tabular}

$t$ statistics in parentheses

Bank fixed effects and year effects included.

${ }^{*} p<0.10,{ }^{* *} p<0.05,{ }^{* * *} p<0.01$

Table 6: Stability indicators - CMP estimation of Equations

(1) and (2)

\begin{tabular}{lccccc}
\hline & $(1)$ & $(2)$ & $(3)$ & $(4)$ & $(5)$ \\
& ROAE & ROAA & NPL & Z-score $_{1}$ & Z-score $_{2}$ \\
\hline Equation 1: performance/resilience, diff-in-diff model & & & \\
CGcode & $13.13^{* * *}$ & $1.659^{* * *}$ & $3.500^{* * *}$ & $2.222^{* *}$ & $8.272^{* *}$ \\
& $(8.64)$ & $(6.51)$ & $(4.07)$ & $(2.20)$ & $(2.31)$ \\
Percentage of ownership & -0.0515 & -0.0120 & 0.0183 & -0.0394 & 0.0150 \\
& $(-0.58)$ & $(-0.88)$ & $(0.40)$ & $(-0.87)$ & $(0.06)$ \\
Logtotalassets & $10.12^{* * *}$ & $1.014^{* * *}$ & $-1.367^{* *}$ & $-5.328^{* * *}$ & 3.016 \\
& $(9.44)$ & $(5.22)$ & $(-2.07)$ & $(-7.63)$ & $(1.02)$ \\
LogGDPperCapita & -0.625 & -0.920 & -0.465 & -2.568 & $-41.42^{* * *}$ \\
& $(-0.16)$ & $(-1.52)$ & $(-0.22)$ & $(-1.19)$ & $(-5.02)$ \\
Inflation & $0.645^{* * *}$ & $0.0785^{* * *}$ & -0.0933 & -0.00493 & $-0.735^{* *}$ \\
Logboardsize & $(4.86)$ & $(3.63)$ & $(-1.20)$ & $(-0.06)$ & $(-2.23)$ \\
\multirow{4}{*}{ UsingBig4 } & 0.216 & $0.137^{*}$ & -0.188 & 0.0751 & 0.841 \\
& $(0.45)$ & $(1.76)$ & $(-0.79)$ & $(0.26)$ & $(0.91)$ \\
CEO duality & -0.609 & 0.622 & 6.155 & -3.842 & $-60.12^{* * *}$ \\
& $(-0.13)$ & $(0.77)$ & $(1.31)$ & $(-1.22)$ & $(-3.14)$ \\
Disclosure & -3.432 & -0.297 & -1.144 & -8.665 & $31.10^{*}$ \\
Sharewomen & $(-0.27)$ & $(-0.15)$ & $(-0.24)$ & $(-1.34)$ & $(1.72)$ \\
Independ & -1.239 & 0.0379 & -1.303 & 0.969 & $13.17^{*}$ \\
Constant & $(-0.34)$ & $(0.06)$ & $(-0.73)$ & $(0.41)$ & $(1.89)$ \\
& -0.198 & 1.488 & 0.239 & 4.446 & -0.125 \\
& $(-0.03)$ & $(1.38)$ & $(0.08)$ & $(1.13)$ & $(-0.01)$ \\
& -2.819 & -0.388 & -2.513 & 2.260 & -0.801 \\
& $(-0.80)$ & $(-0.66)$ & $(-1.20)$ & $(1.02)$ & $(-0.12)$ \\
& $-119.1^{* * *}$ & -4.939 & 25.02 & $102.9^{* * *}$ & $391.2^{* * *}$
\end{tabular}




\begin{tabular}{|c|c|c|c|c|c|}
\hline & $\begin{array}{c}(1) \\
\text { ROAE }\end{array}$ & $\begin{array}{c}(2) \\
\text { ROAA }\end{array}$ & $\begin{array}{c}(3) \\
\text { NPL }\end{array}$ & $\begin{array}{c}(4) \\
\text { Z-score }_{1}\end{array}$ & $\begin{array}{c}(5) \\
\text { Z-score }_{2}\end{array}$ \\
\hline & $(-3.19)$ & $(-0.81)$ & $(1.18)$ & $(4.81)$ & $(4.43)$ \\
\hline Bank-level fixed effects & yes & yes & yes & yes & yes \\
\hline Year effects & yes & yes & yes & yes & yes \\
\hline \multicolumn{6}{|c|}{ Equation 2: prob(CGcode $=1)$, probit model } \\
\hline Legal family of origin & $\begin{array}{c}1.276^{* * *} \\
(8.37)\end{array}$ & $\begin{array}{c}1.328^{* * *} \\
(8.20)\end{array}$ & $\begin{array}{c}1.286^{* * *} \\
(8.48)\end{array}$ & $\begin{array}{c}1.304^{* * *} \\
(8.43)\end{array}$ & $\begin{array}{c}1.282^{* * *} \\
(8.38)\end{array}$ \\
\hline Control of corruption & $\begin{array}{c}0.528^{* * *} \\
(2.84)\end{array}$ & $\begin{array}{c}0.551^{* * *} \\
(2.75)\end{array}$ & $\begin{array}{c}0.408^{* *} \\
(2.29)\end{array}$ & $\begin{array}{c}0.277 \\
(1.55)\end{array}$ & $\begin{array}{l}0.239 \\
(1.35)\end{array}$ \\
\hline Governance effectiveness & $\begin{array}{c}0.0143 \\
(0.06)\end{array}$ & $\begin{array}{c}0.0492 \\
(0.20)\end{array}$ & $\begin{array}{l}0.313 \\
(1.49)\end{array}$ & $\begin{array}{l}0.285 \\
(1.33)\end{array}$ & $\begin{array}{l}0.351^{*} \\
(1.66)\end{array}$ \\
\hline Political stability & $\begin{array}{c}0.317^{* * *} \\
(4.09)\end{array}$ & $\begin{array}{c}0.312^{* * *} \\
(3.67)\end{array}$ & $\begin{array}{c}0.562^{* * *} \\
(7.52)\end{array}$ & $\begin{array}{c}0.563^{* * *} \\
(7.41)\end{array}$ & $\begin{array}{c}0.591^{* * *} \\
(7.85)\end{array}$ \\
\hline Regulatory quality & $\begin{array}{l}-0.121 \\
(-0.60)\end{array}$ & $\begin{array}{l}0.128 \\
(0.61)\end{array}$ & $\begin{array}{l}-0.307 \\
(-1.62)\end{array}$ & $\begin{array}{l}-0.270 \\
(-1.38)\end{array}$ & $\begin{array}{l}-0.297 \\
(-1.53)\end{array}$ \\
\hline Voice and accountability & $\begin{array}{c}-1.992^{* * *} \\
(-9.10)\end{array}$ & $\begin{array}{c}-2.194^{* * *} \\
(-9.54)\end{array}$ & $\begin{array}{c}-2.292^{* * *} \\
(-11.99)\end{array}$ & $\begin{array}{c}-2.124^{* * *} \\
(-11.33)\end{array}$ & $\begin{array}{c}-2.119^{* * *} \\
(-11.30)\end{array}$ \\
\hline logGDPperCapita & $\begin{array}{c}0.135^{*} \\
(1.78)\end{array}$ & $\begin{array}{c}0.0992 \\
(1.24)\end{array}$ & $\begin{array}{c}-0.0394 \\
(-0.60)\end{array}$ & $\begin{array}{c}-0.0209 \\
(-0.31)\end{array}$ & $\begin{array}{c}-0.0298 \\
(-0.45)\end{array}$ \\
\hline Inflation & $\begin{array}{c}0.0129 \\
(1.48)\end{array}$ & $\begin{array}{c}0.00866 \\
(0.94)\end{array}$ & $\begin{array}{c}0.00452 \\
(0.56)\end{array}$ & $\begin{array}{c}0.00316 \\
(0.38)\end{array}$ & $\begin{array}{c}0.00252 \\
(0.30)\end{array}$ \\
\hline Enforcing Contracts & $\begin{array}{c}-1.201^{* * *} \\
(-9.78)\end{array}$ & $\begin{array}{c}-1.262^{* * *} \\
(-9.73)\end{array}$ & $\begin{array}{c}-1.208^{* * *} \\
(-11.59)\end{array}$ & $\begin{array}{c}-1.157^{* * *} \\
(-11.16)\end{array}$ & $\begin{array}{c}-1.154^{* * *} \\
(-11.16)\end{array}$ \\
\hline $\begin{array}{l}\text { Strengths of } \\
\text { investor protection index }\end{array}$ & $\begin{array}{c}0.242^{* * *} \\
(4.56)\end{array}$ & $\begin{array}{c}0.251^{* * *} \\
(4.52)\end{array}$ & $\begin{array}{l}0.365^{* * *} \\
(7.18)\end{array}$ & $\begin{array}{c}0.322^{* * *} \\
(6.28)\end{array}$ & $\begin{array}{c}0.314^{* * *} \\
(6.15)\end{array}$ \\
\hline Constant & $\begin{array}{l}-0.492 \\
(-0.86)\end{array}$ & $\begin{array}{c}-0.0781 \\
(-0.13)\end{array}$ & $\begin{array}{l}0.339 \\
(0.66)\end{array}$ & $\begin{array}{l}0.366 \\
(0.71)\end{array}$ & $\begin{array}{l}0.478 \\
(0.94)\end{array}$ \\
\hline Year effects & yes & yes & yes & yes & yes \\
\hline $\ln \sigma_{1}$ & $\begin{array}{c}2.500^{* * *} \\
(83.54)\end{array}$ & $\begin{array}{c}0.627^{* * *} \\
(19.81)\end{array}$ & $\begin{array}{l}1.509^{* * *} \\
(37.64)\end{array}$ & $\begin{array}{l}1.787^{* * *} \\
(74.14)\end{array}$ & $\begin{array}{c}2.782^{* * *} \\
(81.23)\end{array}$ \\
\hline$\rho_{12}$ & $\begin{array}{c}-0.935^{* * *} \\
(-9.94)\end{array}$ & $\begin{array}{c}-0.849^{* * *} \\
(-8.25)\end{array}$ & $\begin{array}{c}-0.774^{* * *} \\
(-5.83)\end{array}$ & $\begin{array}{c}-0.189^{* *} \\
(-2.28)\end{array}$ & $\begin{array}{c}-0.548^{* * *} \\
(-4.37)\end{array}$ \\
\hline$N$ system & 1551 & 1553 & 1866 & 1917 & 1852 \\
\hline$N$ eq. 1 & 885 & 895 & 645 & 901 & 667 \\
\hline$N$ eq. 2 & 1344 & 1345 & 1709 & 1709 & 1709 \\
\hline
\end{tabular}

$t$ statistics in parentheses

Bank fixed effects and year effects included.

${ }^{*} p<0.10,{ }^{* *} p<0.05,{ }^{* * *} p<0.01$ 
Table 7: Country determinants of CG code publication

\begin{tabular}{|c|c|c|c|c|}
\hline & \multicolumn{4}{|c|}{ Dep var: $\operatorname{prob}(\mathrm{CG}$ code $=1)$} \\
\hline & (1) & (2) & (3) & (4) \\
\hline Legal family of origin & $\begin{array}{c}0.540^{* *} \\
(2.49)\end{array}$ & $\begin{array}{c}0.467^{* * *} \\
(3.61)\end{array}$ & $\begin{array}{c}1.089^{* * *} \\
(6.69)\end{array}$ & $\begin{array}{c}1.775^{* * *} \\
(4.20)\end{array}$ \\
\hline Strengths of investor protection index & $\begin{array}{l}-0.164 \\
(-1.32)\end{array}$ & - & - & $\begin{array}{c}0.760^{* * *} \\
(3.04)\end{array}$ \\
\hline Extent of director liability index & $\begin{array}{c}-0.00636 \\
(-0.11)\end{array}$ & - & - & $\begin{array}{c}-0.232^{* *} \\
(-2.49)\end{array}$ \\
\hline Ease of shareholder suits index & $\begin{array}{c}0.106^{*} \\
(1.84)\end{array}$ & - & - & $\begin{array}{c}-0.0118 \\
(-0.14)\end{array}$ \\
\hline Enforcing contracts & $\begin{array}{c}-0.00178^{* * *} \\
(-5.48)\end{array}$ & - & - & $\begin{array}{c}-0.00355^{* * *} \\
(-5.70)\end{array}$ \\
\hline Growth rate & - & $\begin{array}{c}0.00397 \\
(0.36)\end{array}$ & - & $\begin{array}{c}-0.0314 \\
(-1.02)\end{array}$ \\
\hline logGDPpercapita & - & $\begin{array}{c}0.111^{*} \\
(1.83)\end{array}$ & - & $\begin{array}{c}0.573^{* * *} \\
(3.61)\end{array}$ \\
\hline Inflation & - & $\begin{array}{c}0.00744 \\
(1.22)\end{array}$ & - & $\begin{array}{c}0.0183 \\
(1.00)\end{array}$ \\
\hline Control of corruption & - & - & $\begin{array}{c}-0.487^{*} \\
(-1.82)\end{array}$ & $\begin{array}{c}0.0185 \\
(0.04)\end{array}$ \\
\hline Governance effectiveness & - & - & $\begin{array}{c}1.769^{* * *} \\
(5.22)\end{array}$ & $\begin{array}{l}-0.235 \\
(-0.40)\end{array}$ \\
\hline Political stability & - & - & $\begin{array}{c}0.410^{* * *} \\
(3.53)\end{array}$ & $\begin{array}{c}0.385^{* *} \\
(2.00)\end{array}$ \\
\hline Regulatory quality & - & - & $\begin{array}{l}0.101 \\
(0.35)\end{array}$ & $\begin{array}{l}-0.439 \\
(-0.93)\end{array}$ \\
\hline Rule of Law & - & - & $\begin{array}{c}-1.385^{* * *} \\
(-3.50)\end{array}$ & $\begin{array}{l}0.331 \\
(0.59)\end{array}$ \\
\hline Voice and accountability & 一 & - & $\begin{array}{c}-1.056^{* * *} \\
(-6.16)\end{array}$ & $\begin{array}{c}-2.777^{* * *} \\
(-5.17)\end{array}$ \\
\hline Constant & $\begin{array}{c}1.510^{* * *} \\
(3.52)\end{array}$ & $\begin{array}{c}-1.756^{* * *} \\
(-3.57)\end{array}$ & $\begin{array}{c}-1.622^{* * *} \\
(-5.88)\end{array}$ & $\begin{array}{c}-6.020^{* * *} \\
(-4.02)\end{array}$ \\
\hline$N$ & 350 & 449 & 466 & 338 \\
\hline
\end{tabular}


Table 8: Country determinants of CG code publication

\begin{tabular}{|c|c|c|c|c|}
\hline & \multicolumn{4}{|c|}{ Dep var: $\operatorname{prob}(\mathrm{CG}$ code $=1)$} \\
\hline & (1) & (2) & (3) & (4) \\
\hline Legal family of origin & $\begin{array}{c}0.540^{* *} \\
(2.49)\end{array}$ & $\begin{array}{c}0.467^{* * *} \\
(3.61)\end{array}$ & $\begin{array}{c}1.089^{* * *} \\
(6.69)\end{array}$ & $\begin{array}{c}1.775^{* * *} \\
(4.20)\end{array}$ \\
\hline Strengths of investor protection index & $\begin{array}{l}-0.164 \\
(-1.32)\end{array}$ & - & - & $\begin{array}{c}0.760^{* * *} \\
(3.04)\end{array}$ \\
\hline Extent of director liability index & $\begin{array}{c}-0.00636 \\
(-0.11)\end{array}$ & - & - & $\begin{array}{c}-0.232^{* *} \\
(-2.49)\end{array}$ \\
\hline Ease of shareholder suits index & $\begin{array}{c}0.106^{*} \\
(1.84)\end{array}$ & - & - & $\begin{array}{c}-0.0118 \\
(-0.14)\end{array}$ \\
\hline Enforcing contracts & $\begin{array}{c}-0.00178^{* * *} \\
(-5.48)\end{array}$ & - & - & $\begin{array}{c}-0.00355^{* * *} \\
(-5.70)\end{array}$ \\
\hline Growth rate & - & $\begin{array}{c}0.00397 \\
(0.36)\end{array}$ & - & $\begin{array}{c}-0.0314 \\
(-1.02)\end{array}$ \\
\hline logGDPpercapita & - & $\begin{array}{c}0.111^{*} \\
(1.83)\end{array}$ & - & $\begin{array}{c}0.573^{* * *} \\
(3.61)\end{array}$ \\
\hline Inflation & - & $\begin{array}{c}0.00744 \\
(1.22)\end{array}$ & - & $\begin{array}{c}0.0183 \\
(1.00)\end{array}$ \\
\hline Control of corruption & - & - & $\begin{array}{c}-0.487^{*} \\
(-1.82)\end{array}$ & $\begin{array}{c}0.0185 \\
(0.04)\end{array}$ \\
\hline Governance effectiveness & - & - & $\begin{array}{c}1.769^{* * *} \\
(5.22)\end{array}$ & $\begin{array}{l}-0.235 \\
(-0.40)\end{array}$ \\
\hline Political stability & - & - & $\begin{array}{c}0.410^{* * *} \\
(3.53)\end{array}$ & $\begin{array}{c}0.385^{* *} \\
(2.00)\end{array}$ \\
\hline Regulatory quality & - & - & $\begin{array}{l}0.101 \\
(0.35)\end{array}$ & $\begin{array}{l}-0.439 \\
(-0.93)\end{array}$ \\
\hline Rule of Law & - & - & $\begin{array}{c}-1.385^{* * *} \\
(-3.50)\end{array}$ & $\begin{array}{l}0.331 \\
(0.59)\end{array}$ \\
\hline Voice and accountability & - & - & $\begin{array}{c}-1.056^{* * *} \\
(-6.16)\end{array}$ & $\begin{array}{c}-2.777^{* * *} \\
(-5.17)\end{array}$ \\
\hline Constant & $\begin{array}{c}1.510^{* * *} \\
(3.52)\end{array}$ & $\begin{array}{c}-1.756^{* * *} \\
(-3.57)\end{array}$ & $\begin{array}{c}-1.622^{* * *} \\
(-5.88)\end{array}$ & $\begin{array}{c}-6.020^{* * *} \\
(-4.02)\end{array}$ \\
\hline$N$ & 350 & 449 & 466 & 338 \\
\hline
\end{tabular}

